\title{
Introduction: Why Examine Rising Powers' Role in Peacebuilding?
}

\section{Cedric de Coning and Charles T. Call}

Despite progress since the Cold War in reaching negotiated settlements in civil wars, efforts to consolidate peace with effective governance have proven challenging in places as diverse as the Congo, Afghanistan, Haiti, Iraq, Central Africa, and the Middle East. Two decades ago international peacebuilding was understood as a centrally coordinated package of interventions aimed at resolving a conflict by addressing its root causes. International institutions were thought to have acquired the scientific knowledge and the practical expertise to "build" peace (Chandler 2012). The problem-recurring violent conflict-was usually located in weak and failing states in the Global South, and the solutions required that these states adopt liberal state practices-democratic politics, free-market policies, and rights-based approaches to Rule of Law-that have proven successful in the Western state-formation experience.

C. de Coning $(\bowtie)$

Norwegian Institute of International Affairs, Oslo, Norway

Peacekeeping and Peacebuilding Unit, ACCORD, Durban, South Africa

C.T. Call

School of International Service, American University, Washington, DC, USA

(C) The Author(s) 2017

C.T. Call, C. de Coning (eds.), Rising Powers and

Peacebuilding, Rethinking Peace and Conflict Studies,

DOI 10.1007/978-3-319-60621-7_1 
Over the last decade this shared understanding of peacebuilding has been significantly eroded. The belief in the transformative power of international peacebuilding has waned because many of the interventions undertaken over the preceding period, and especially those in the Balkans, Iraq, Afghanistan, and in Africa's Great Lakes and Horn regions, are widely understood to have been ineffective. It is increasingly less clear what type of problems, if any, can be resolved through international peacebuilding, and how intrusive and prescriptive such interventions should be (Richmond 2015).

Peacebuilding "successes" in Central America, Southern and West Africa, and the Balkans are plagued by problems such as criminal violence, corruption, political exclusion, or continued instability (Call and Wyeth 2008). The failure of peacebuilding to deliver sustained peace has combined with a push from rising powers against Western dominance, to produce a turn to the Global South as a source for more legitimate and effective responses to mass organized violence in the world.

At the same time, debates over and institutions associated with peacebuilding have become a central focus of post-conflict contestation. A United Nations (UN) Peacebuilding Commission created in 2005 is the sole UN organ where Northern and Southern UN member states come together to discuss peace and security issues outside of the General Assembly (Jenkins 2013). While parts of the UN's peacebuilding architecture, such as the UN Peacebuilding Fund, proved innovative and effective, ${ }^{1}$ the performance overall of the UN's peacebuilding architecture has not met expectations (de Coning and Stamnes 2016). Two major UN reviews were undertaken in 2015 , one taking stock of peace operations and the other assessing the peacebuilding architecture (Report of the High-Level Independent Panel on United Nations Peace Operations 2015; Advisory Group of Experts for the 2015 Review of the United Nations Peacebuilding Architecture 2015). Both shied away from embracing the concept of peacebuilding and instead opted for the new emerging but still vague concept of sustaining peace. As a result of these reviews, adjustments are being introduced to both the concept of peacebuilding and to how, especially, the UN Peacebuilding Commission functions.

Peacebuilding also emerged as an important new dimension in the negotiations over the post-2015 development agenda (Richmond and Tellidis 2013) and resulted in peacebuilding-related issues featuring in several of the goals of the new sustainable development goals of Agenda 
2030, including especially in Goal 16, which aims to promote peaceful and inclusive societies for sustainable development, to provide access to justice for all, and to build effective, accountable, and inclusive institutions at all levels.

In another development, a group of 19 self-identified fragile states like East Timor and Liberia have been at the forefront of the New Deal (International Dialogue on Peacebuilding and Statebuilding 2017; Wyeth $2012,7-12)$. It seeks to transform the way international assistance to these countries is managed by placing the countries themselves in the driver's seat when it comes to determining what causes their fragility, setting their own priorities, planning their own paths to resilience, and managing the relationship with their international partners.

Onto this stage new actors like the BRICS (Brazil, Russia, India, China, and South Africa) (de Coning et al. 2014) and a number of other prominent regional powers in the Global South like Indonesia and Turkey have emerged as new "donors" that advance their own political and technical approaches to peacebuilding (de Carvalho and de Coning 2013). Many of these countries have established development cooperation agencies that prioritize South-South technical assistance, new less conditional modes of operating, appropriate peer-provided guidance on political processes, and a celebration of national ownership and empowerment (Mawdsley 2012). These Southern approaches are seen by many as technically more appropriate and thus a further improvement to the liberal Western model (Chaturvedi et al. 2012). They are also seen as an alternative or antidote to dominant liberal approaches (Campbell et al. 2011). These approaches seem to answer the first of the two core deficiencies cited about current approaches: that they are Western dominated and that they ignore local contextual dynamics and opportunities.

Although there is a growing literature about the development roles and approaches of the rising powers, the research on their roles and approaches to peacebuilding is still underdeveloped. This book aims to make a contribution to this field because the entry of the rising powers into the peacebuilding field is likely to have significant implications for how the UN and other international and regional organizations, as well as both the traditional donors and the recipient countries, view peacebuilding in the future. Will the entry of the rising powers into the field of peacebuilding fundamentally alter how we understand and undertake peacebuilding a decade or more from now? 


\section{Our Aim with This Book}

With this book, we seek to answer the following central question: What exactly is new and innovative about the peacebuilding approach of the rising powers from the Global South, and what are the implications of these new approaches for peacebuilding?

A number of related questions help to further inform our central question, such as: How are these rising powers changing the peacebuilding landscape? What influence are they having on the way the African Union (AU), Association of Southeast Asian Nations (ASEAN), European Union (EU), United Nations (UN), North Atlantic Treaty Organization (NATO), and traditional bilateral donors [Organization for Economic Cooperation and Development (OECD)] are approaching peacebuilding? To what degree does the engagement of rising powers with fragile states have peacebuilding objectives (theories of change aiming to influence relapse into violent conflict)? How do these rising powers differentiate between development and peacebuilding? How does the change model (theory of change) used by these rising powers differ from the Western liberal peacebuilding model? To what degree are peacebuilding projects undertaken by these rising powers locally grounded and owned? To what degree are their projects perceived to be successful by the recipient countries (people and governments)? What innovations, lessons learned, and best practices have come about as a result of the entry of the rising powers into the peacebuilding field? To what degree are these rising powers concerned with results, and what kind of monitoring and evaluation systems do they employ?

In our efforts to answer these questions, we provide a structured, critical analysis of the values, intent, and content of the peacebuilding initiatives of a number of rising powers. We compare them to one another and to the approaches of the UN and the EU. In our analysis, we offer new theoretical claims about the role of the Global South in peacebuilding, rooted in our empirical work on Somalia, Afghanistan, and Myanmar as well as on the specific policies and approaches of Brazil, India, Indonesia, South Africa, and Turkey.

\section{Our ApProAch}

We have selected five rising powers for this book, namely Brazil, India, Indonesia, South Africa, and Turkey. The rising power concept is ambiguous. All of these countries are regional powers, and some have been long- 
standing important or middle powers on the global stage. Some like Brazil have sought a more high-profile role over the past decade, whereas others like Indonesia have sought a low-profile role. We have opted to use the rising power concept as indicative of one of the characteristics that these countries have in common, that is their influence in the global order is increasing, or their influence (soft and hard power) has been on the rise. In some cases, such as Brazil and Turkey, domestic instability has caused turbulence for foreign policy as well. Yet the overall status of these countries as rising powers remains pertinent. This aspect is especially relevant in the context of this study in that their influence on peacebuilding is now starting to be felt. Up to now these countries had little or no influence on how peacebuilding was understood or practiced, apart from participating in debates at the UN, and even there, such debates were not initiated or framed by these countries.

Our hypothesis is that as their influence on global governance increases over time, their approaches to peacebuilding may significantly influence how peacebuilding will be understood and practiced in global governance in the future. If so, then what can we know now about how these countries understand and practice peacebuilding that may give us an indication of how they may influence the future of peacebuilding?

An alternative hypothesis we explore is that the rising powers' understanding and approach to peacebuilding may change as they engage more with peacebuilding in ways similar to that of the traditional donors. For instance, the more the rising powers engage in development cooperation type initiatives with the aim of contributing to international peace and security, the more they will come under pressure-domestically and internationally - to assess the effectiveness of their approach to peacebuilding. The rise of these countries may thus not only result in them influencing how peacebuilding is viewed as part of global governance in future, but the pressures and experiences of doing so may also influence how these countries themselves view and approach peacebuilding nationally. According to this hypothesis, the experience of taking up not just national responsibility but also international responsibility for global peace and security will influence the understanding of concepts like peacebuilding within the rising powers. It may result in their approaches to peacebuilding adjusting over time and arriving at a position that is much closer to where the traditional approach to peacebuilding is today than their current approaches. If so, we will explore if we can see any indications at this stage that would support such a maturing to a global responsibility hypothesis. 
These specific countries have been selected to represent a sample of the rising power phenomenon. We are not making an argument that these countries are THE rising powers, but rather that they represent a sample, including leading examples of rising powers from Africa, Asia, Latin America, the Middle East, and South East Asia. Three of these countriesBrazil, India, and South Africa-are members of the BRICS, and three are also members of another South-South cooperation forum called IBSA (India, Brazil, and South Africa) (Abdenur et al. 2014; Piccone 2015; Stuenkel 2014). Countries like Brazil, South Africa, and Turkey are obviously important players in their regional context and have global impact on several issues, whilst India is among the major global economic and political actors.

Most of our contributors are researchers from these countries. We have consciously opted to select contributors that can assist the reader to understand these countries' approaches to peacebuilding in the context and narrative articulated by these countries themselves, rather than offer a Western interpretation. The book thus includes chapters on each of these countries-Brazil, India, Indonesia, South Africa, and Turkey-that explore how peacebuilding is understood in these countries, including in the context of their local experience, history, and culture. Each of these chapters also explains what kind of peacebuilding activities these countries undertake and discuss a few specific examples. In this way, the book will provide a more systematic understanding of the commonalities, differences, and heretofore unexposed patterns in the origins and shifts of rising powers' roles in peacebuilding.

Most of our contributors have worked extensively with (or inside) organizations like the UN and the AU, governments like India, South Africa, and the USA, non-governmental organizations, universities and think tanks, as well as in operations and programs in the field. This understanding of key audiences and actual peacebuilding and related activities has greatly facilitated the aim of helping infuse the learning and perspectives of these rising powers into global policies and practices, thereby recognizing that peacebuilding practice rests in multiple domains and levels.

The book explicitly wrestles with understanding the strategic goals and interests of these rising powers. Rather than making assumptions about the roles and motives of these countries on their new roles, the book explores the various complex motives and political divisions within these rising powers that drive their roles and approaches. Further, the book analyzes the multiple coalitions and actors within these countries, and their 
expressions in operations abroad offer an understanding of how much programs reflect national cultures or philosophical approaches. In addition, the book shows how ephemeral they may be depending on the government in power and its internal political calculations, and the bureaucratic politics of these countries' approaches. Without adopting strict public policy theoretical frameworks, the book interrogates these internal political and economic dimensions behind the rising powers' diverse and evolving roles in peacebuilding.

The fact that researchers from these rising powers critically interpret and analyze their own experiences ensures that the values, perspectives, and approaches of these rising powers are explicitly compared. Throughout the various chapters, our contributors explore the assumptions that underlie our chosen approaches, helping hone in on what exactly is distinctive and innovative about Northern and Southern approaches to peacebuilding.

In addition to the country chapters, the book also includes three casestudy chapters. Our contributors have looked at Afghanistan, Myanmar, and Somalia as examples of countries where rising powers such as India, Indonesia, China, and Turkey have actively engaged in peacebuilding initiatives. We opted to use a "structured, focused" method for our case studies; through asking a common set of questions across the cases (George and Bennett 2005), this book provides a framework that enables comparison across the three case studies. This marks a shift from the contemporary single case study and ad hoc case study approach that dominates current research on peacebuilding.

Although there is no single "Western" or dominant template for peacebuilding, one may glean common characteristics of dominant multilateral institutions and bilateral donors. The EU approach is a good example of the traditional or established approach to peacebuilding as practiced by the donor countries that are members of the OECD. Through the OECD these countries have a codified approach to development assistance and peacebuilding, through agreed approaches such as the "The Principles for Good International Engagement in Fragile States and Situations". ${ }^{2}$ In general, the approach of the UN Secretariat and of these European institutions can be characterized as top-down, institution-focused rather than process-focused, state-centric, and on a relatively short time horizon (Call and Collin 2015; Stamnes 2016). The policies and practices of many OECD bilateral donors also adhere to these traits, as well as conditionality on good governance. Powerful countries have thus far shaped how the concept and practice of peacebuilding are understood in the UN. Yet as 
the influence of the rising powers increases, the UN's understanding of and approach to peacebuilding offers a test or window into our competing hypotheses of whether rising powers will reshape the dominant multilateral and bilateral approaches, or whether they will, in turn, be shaped by the dominant approaches and discourse and come to resemble more conventional approaches.

\section{How Do We Conceptualize Peacebuilding?}

For the purposes of this book, we have opted to use a very broad understanding of peacebuilding. If not, we would have undermined our attempt to understand how the rising powers view peacebuilding by imposing a definition and approach to peacebuilding influenced by the traditional understanding and approach to peacebuilding. We have thus opted to use a broad understanding of peacebuilding to mean any deliberate programlike effort that has a conflict-resolution theory of change that is meant to influence preventing a lapse into violent conflict or to sustain peace.

We have considered using the UN definition(s) and approach to peacebuilding, as it represents a globally agreed concept, but we have found that there is a considerable gap between what many Member States view as the role of an international body like the UN when it comes to peacebuilding, and how they choose to deal with such issues domestically. For instance, whilst the USA engages in debates on peacebuilding at the UN, the concept is not prominently used domestically in the policies or approaches of the US government.

We have thus opted against using the UN definition for fear of contaminating our study of peacebuilding in the rising powers by imposing an external concept. Instead we have tasked our contributors to take a "bottom-up" approach and to seek out national concepts and understandings that approximate this broad theory of change approach to peacebuilding. Even this broad approach to peacebuilding has proven challenging at times. In our concluding analysis, we discuss these definitional and conceptual challenges in greater detail.

\section{The Chapters that Follow}

The first section of the volume presents national approaches to peacebuilding in their own contexts. The authors seek to describe, on their own terms, the national approaches to peacebuilding. Each researcher sought 
to specify what various national officials and other constituencies mean by the term "peacebuilding" and to identify what other terms are deployed in official documents and discourse that refer to bundle of activities that might in traditional circles be labeled "peacebuilding." In these analyses of national approaches, the authors sought to describe each approach as it has emerged and how it is bureaucratically circumscribed, in the terms of each country context. Each of these chapters was authored by researchers living in the country studied. These authors all conducted interviews with pertinent diplomatic and development officials, mainly in the capitals, but also in some cases in the missions to the UN in New York. Some of the authors of these analyses of national approaches also drew on field research in the countries where these operations are taking place.

This section begins with Abdenur and Call's analysis of Brazil, which has been among the more vocal and visible on peacebuilding policy in the UN and in fora of the Global South such as the India-Brazil-South Africa Dialogue Forum (IBSA) and the Community of Portuguese-Language Countries. It then moves to Alexandra's analysis of Indonesia, one of the newer actors in regional peacebuilding active especially in mediation facilitation in Southeast Asia. The next chapter by P. K. Singh details the long record of India in peacebuilding policy and activities from its earliest days as an independent country, explaining its strong emphasis on nationally owned, state-led development. Sazak and Woods' chapter on Turkey's role in peacebuilding reflects an expanded role in humanitarian diplomacy and its identity as a Muslim nation seeking to play a more active role in the Middle East. Finally, South African leadership seeking to support peace processes and post-conflict efforts in the continent, including peace operations, is the subject of Nyuykonge and Siphamandla's final chapter, among other national approaches to peacebuilding.

The second section of the book presents three case studies that illustrate the role of rising powers in specific countries in transition. Few people recognize India's role as the fifth largest donor in Afghanistan in the twenty-first century, and Sinha's chapter contrasts that role with the approach of traditional donors in that conflict-ridden country. The personal interest of then Prime Minister Recep Erdoğan in Somalia's strife helped Turkey take a prominent role in that country. Its humanitarian, mediation, and institution-building support helped define Turkey's approach to peacebuilding, as analyzed by Sazak and Woods in this case study. Finally, Indonesia, China, and other rising powers have been important supporters of Myanmar's transition to democracy and in efforts to 
address the diverse communal armed conflicts. The chapter by Alexandra and Lanteigne examines those peacebuilding efforts.

A concluding chapter analyzes these empirics, cataloging several common characteristics of what might be considered common to the diverse group of rising powers examined in this study. Some of the characteristics are stronger in some countries than others. Furthermore, we identify some of the important differences among rising powers' peacebuilding activities. These are important as they show how trends may evolve in different ways and reflect the various motives that underlie the relatively new engagement of rising powers as protagonists in peacebuilding efforts in partner countries. The conclusion also analyzes the influence rising powers' approaches have had on traditional institutions and their peacebuilding policies and practices.

Finally, we suggest some implications for theorizing about the broader political and strategic role of emerging or middle powers. As the number of armed conflicts rises and the numbers of their victims reach historic highs not seen since World War II, "peacebuilding" is an increasingly important arena for addressing global violence and its human consequences. It is also an important window on North-South relations in evolving global governance, including the identities of these countries on the world stage. As such, we anticipate that this analysis will contribute not just to policy debates about peacebuilding, but to theoretical discussions of global governance.

\section{Notes}

1. The editors, Charles T. Call and Cedric de Coning, have served in their personal capacities on the UN Secretary-General's Advisory Group for the UN Peacebuilding Fund. De Coning's term was from 2012 to 2015, while Call served two terms from 2012 to 2017.

2. In 2009 the Development Assistance Committee (DAC) of the OECD established a subsidiary body called the International Network on Conflict and Fragility (INCAF). Through INCAF, DAC members participated in the development of the New Deal for Engagement in Fragile States in partnership with the $\mathrm{g} 7+$, which is a voluntary association of 20 countries that are or have been affected by conflict, as well as civil society. This collaboration was done under the aegis of the International Dialogue on Peacebuilding and Statebuilding. See: http://www.oecd.org/dac/governance-peace/ conflictfragilityandresilience/iefs.htm, accessed on July 1, 2016. 


\section{REFERENCES}

Abdenur, Adriana Erthal, Maiara Folly, Kayo Moura, Sergio A.S. Jordão, and Pedro Maia. 2014. The BRICS and the South Atlantic: Emerging Arena for South-South Cooperation. South African Journal of International Affairs 21(3): 303-319.

Advisory Group of Experts for the 2015 Review of the United Nations Peacebuilding Architecture. 2015. The Challenge of Sustaining Peace. New York: United Nations.

Call, Charles T., and Katy Collin. 2015. The United Nations Approach to Peacebuilding. Paper prepared for "Rising Powers and Peacebuilding" project. www.risingpowersandpeacebuilding.org

Call, Charles T., and Vanessa Wyeth, eds. 2008. Building States to Build Peace. Boulder, CO: Lynne Rienner.

Campbell, Susanna, David Chandler, and Meera Sabaratnam, eds. 2011. A Liberal Peace?: The Problems and Practices of Peacebuilding. London: Zed Books.

Chandler, David. 2012. Resilience and Human Security: The Post-interventionist Paradigm. Security Dialogue 43(3): 213-229.

Chaturvedi, Sachin, Thomas Fues, and Elizabeth Sidiropoulos. 2012. Development Cooperation and Emerging Powers: New Partners Old Patterns? London: Zed Books.

de Carvalho, Benjamin, and Cedric de Coning. 2013. Rising Powers and the Future of Peacekeeping and Peacebuilding (NOREF Report, 14). Oslo: Norwegian Peacebuilding Resource Centre.

de Coning, Cedric, and Eli Stamnes, eds. 2016. UN Peacebuilding Architecture: The First 10 Years. New York: Routledge.

de Coning, Cedric, Thomas Mandrup, and Liselotte Odgaard, eds. 2014. BRICS and Coexistence: An Alternative Vision of World Order. New York: Routledge.

George, Alexander L., and Andrew Bennett. 2005. Case Studies and Theory Development in the Social Sciences. Cambridge, MA: Massachusetts Institute of Technology Press.

High-Level Independent Panel on United Nations Peace Operations. 2015. Uniting our Strengths for Peace: Politics, Partnership and People. New York: United Nations.

International Dialogue on Peacebuilding and Statebuiding. 2017. A New Deal for Engagement in Fragile States. Factsheet available at http://www.pbsbdialogue.org/media/filer_public/07/69/07692de0-3557-494e-918e18df00e9ef73/the_new_deal.pdf

Jenkins, Rob. 2013. Peacebuilding: From Concept to Commission. New York: Routledge.

Mawdsley, Emma. 2012. From Recipients to Donors: Emerging Powers and the Changing Landscape. London: Zed Books. 
Piccone, Ted. 2015. Five Rising Democracies. Washington, DC: Brookings Institution Press.

Richmond, Oliver P. 2015. After Liberal Peace: The Changing Concept of Peacebuilding. RSIS Commentary No. 272. Singapore: S. Rajaratnam School of International Studies.

Richmond Oliver P., and Ioannis Tellidis. 2013. The BRICS and International Peacebuilding and Statebuilding (NOREF Report 1). Oslo: Norwegian Peacebuilding Resource Centre.

Stamnes, Eli. 2016. The European Union and Peacebuilding. Paper prepared for "Rising Powers and Peacebuilding" project. www.risingpowersandpeacebuilding. org

Stuenkel, Oliver. 2014. India-Brazil-South Africa Dialogue Forum: The Rise of the Global South. New York: Routledge.

Wyeth, Vanessa. 2012. Knights in Fragile Armor: The Rise of the 'G7+'. Global Governance 18(2): 7-12.

Cedric de Coning is Senior Research Fellow in the Peace and Conflict Studies Research Group at NUPI, and Senior Advisor on Peacekeeping and Peacebuilding for ACCORD.

Charles T. "Chuck" Call is Associate Professor of International Peace and Conflict Resolution, School of International Service, American University, Washington DC.

Open Access This chapter is licensed under the terms of the Creative Commons Attribution 4.0 International License (http://creativecommons.org/licenses/ by $/ 4.0 /)$, which permits use, sharing, adaptation, distribution and reproduction in any medium or format, as long as you give appropriate credit to the original author(s) and the source, provide a link to the Creative Commons license and indicate if changes were made.

The images or other third party material in this chapter are included in the chapter's Creative Commons license, unless indicated otherwise in a credit line to the material. If material is not included in the chapter's Creative Commons license and your intended use is not permitted by statutory regulation or exceeds the permitted use, you will need to obtain permission directly from the copyright holder.

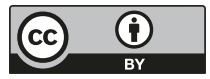

